\title{
The International Core Literacy Cultivation of Traffic Vocational College Students under the Background of "the Belt and Road"
}

\author{
Haiying Fan \\ Shaanxi College of Communication Technology \\ Xi'an 710018, China
}

\begin{abstract}
Core literacy is a training guide for the Ministry of education in the process of internationalization of education in China. Especially in the case of China's opening door, it is of great significance to explore the core literacy training of Higher Vocational Students under the "the Belt and Road" initiative. Based on the investigation of the core literacy of traffic vocational students, this paper puts forward a core literacy system which integrates patriotism, international outlook and high skills, and some measures and suggestions, such as changing the idea of running a school, introducing overseas construction standards and other post-literacy into the teaching system, opening international vocational qualification certificates for transportation and training for international vocational skills competitions.
\end{abstract}

Keywords-"the Belt and Road", transportation vocational education, internationalization and core literacy

\section{INTRODUCTION}

In the past six years since the construction of "the Belt and Road", China and the other countries along the route have opened a large number of cooperation in ports, railways, highways, electricity, aviation, communications and other fields, effectively improving the infrastructure level of these countries. In conjunction with relevant countries, China has formulated strategic plans such as Greater Mekong Subregional Transport Strategy 2030, Central Asia Regional Economic Cooperation Railway Development Strategy 2030, ChinaASEAN Transport Cooperation Strategic Plan and ChinaPakistan Economic Corridor Transport Infrastructure Special Plan.[1]

The development and changes of transportation industry brought about by the "the Belt and Road" initiative brings new requirements for the demand for transportation talents. Whether in the theoretical aspect of the concept of "the Belt and Road" initiative or in promoting the implementation of various projects, the key needs.[2] In October 2015, the Ministry of Education issued the Action Plan for Innovation and Development of Higher Vocational Education (2015-2018), and explicitly proposed the expansion of vocational education cooperation with the countries along the "the Belt and Road". At present, various transportation vocational colleges and educational institutions have launched and carried out various international talent training projects and programs. Some transport vocational colleges will carry out internationalization projects into the talent training program, others will incorporate the training of foreign students into the talent training program, and even some transport vocational colleges will develop overseas training points as an international talent training program. However, the training objects in these training programs are limited to some vocational students and under the background of "the Belt and Road" construction, it is necessary to fully train the International Literacy of transportation vocational students.

\section{THE CONNOTATION OF INTERNATIONAL CORE LITERACY OF TRAFFIC VOCATIONAL COLLEGE STUDENTS}

\section{A. The Connotation of International Core Literacy}

The research on College Students' core literacy began in the 1990s. There are "literacy research aiming at lifelong learning", "core literacy research aiming at ability" and "core literacy research aiming at individual success and harmonious development of society" abroad. The concept of core literacy education was introduced into China in the 21st century. The Ministry of Education and educators began to study students' core literacy one after another and proposed that core literacy is the essential character and key ability that students should possess to meet the needs of lifelong development and social development. Under the initiative of "the Belt and Road", how to deal with the training of international talents in higher vocational colleges should answer how to train people's problems.

\section{B. The Connotation of Internationalization Core Literacy of Traffic Vocational Students}

On September 13, 2016, a conference on the research results of Core Literacy of Chinese Students' Development was held at Beijing Normal University, and the general framework of Core Literacy of Chinese Students' Development was officially released. It is pointed out that the comprehensive performance of students' core literacy in China is as follows: social responsibility, national identity, international understanding; humanistic connotation, scientific spirit, aesthetic interest; physical and mental health, learning to learn, practice and innovation. From this we can see that international understanding is an important part of students' core literacy.

Project Source: 13th Five-Year Plan of Shaanxi Province (Question No.: SGH17V044) 
In order to get a deeper understanding of the specific structure of the core competence of transportation vocational students, The concrete composition of international core literacy of transportation vocational students is deeply analyzed based on the relationship and dynamic balance between the systems and elements of the "the Belt and Road", and the experimental class is selected for experimental observation, and the core international literacy related to the cultivation of students' humanistic and natural systems is summarized, mainly including patriotism, international outlook and high skills. Among them, patriotism is fundamental, which is the goal of education and the most important of the first level. It is the concrete realization of patriotism through national and local education. The international outlook is a new requirement. Internationalized skilled talents must have an international concept and vision, and a corresponding knowledge system. "the Belt and Road" plays a substantial role in cultural, political, social and moral education. High skill refers to contributing to the construction of "the Belt and Road" and requires good skills. In the 64 countries along "the Belt and Road", the relationship between people and land is extremely complex. If the traffic vocational students want to better serve the construction of the "the Belt and Road" area, they must have excellent professional accomplishment.

III. ANALYSIS ON THE SURVEY RESULTS OF VOCATIONAL COLLEGE STUDENTS IN THE BACKGROUND OF "THE BELT AND ROAD"

\section{A. A Survey of Traffic Vocational Students' Cognition of "the Belt and Road" Initiative}

According to the survey results, $90.1 \%$ of the students said they knew the "one belt and one way" initiative, $53.2 \%$ of the students thought it would have a great impact on their future life, $63.55 \%$ of the students thought it would bring about changes in employment opportunities, and $71.6 \%$ of students believe that we should strive to learn scientific and cultural knowledge to seize the development opportunities brought by "the Belt and Road". It shows that the majority of traffic vocational students believe that the construction of "the Belt and Road" will have a great correlation with our working students. However, $87.65 \%$ of the students expressed no knowledge of the humanities, geography, religion, law and other related knowledge along the "along the road". 57\% of the students thought that the lack of professional knowledge could be the biggest obstacle to the construction of "the Belt and Road", while 91.13\% thought that language was the biggest obstacle. The region covers 4.4 billion people, accounting for $63 \%$ of the world's total population, and is a multi-ethnic place. According to statistics, there are at least 95 languages involved in 175 countries that have established diplomatic relations with China, but at present only one university in China can offer 54 non-general language courses, while other foreign language universities can only offer more than 20 non-general language courses.[4] $72.3 \%$ of the students believe that professional knowledge and professional skills will become a major challenge along the "one belt" road.

When asked, do you know the customs of "along the road"? Only $19.21 \%$ of the students chose to have a better understanding, while the rest did not. When asked, do you know the geographical environment of the countries along the belt? Only $23.15 \%$ of the students knew one thing. When asked, do you know the transportation cooperation projects along the "one belt" road? Only $18.23 \%$ of the students said they knew something. From the results of the questionnaire survey, it is necessary to carry out the training of international core literacy under the initiative of "the Belt and Road", and the training of core literacy will provide better human resources for the construction of "the Belt and Road".

\section{B. Investigation Results of Transportation Enterprises along the "the Belt and Road" Construction}

A questionnaire survey was conducted on the transportation enterprises with the cooperation projects along the "the Belt and Road". From the survey results, it is the basic requirement for practitioners to have an international perspective, to understand the relevant construction codes and laws of the country, to understand the historical and cultural background of the country or region, and to communicate in the local language. For those projects involving material flow and transportation investment and financing, there is an urgent need for talents who are familiar with the country's settlement and business law.

\section{Survey on Teachers and Schools of Traffic Talents Trainers}

Through the analysis of big data in home pages of transportation vocational colleges, almost all transportation vocational colleges are trying to seize the development opportunities brought by the "the Belt and Road" initiative. But in-depth visits found that some colleges and universities are not in place to implement the international exchange awareness is not strong, still staying as long as students have a technical expertise, training the internationalization awareness of traffic vocational students is a waste of effort. Most transportation vocational colleges mainly set up special colleges to carry out international exchanges and cooperation, mainly involving individual students. However, the secondary teaching units did not introduce this internationalization into the daily training system, resulting in students' weak awareness of internationalization.

\section{Cultivation OF CORE COMPETENCE OF} INTERNATIONAL TALENTS IN TRANSPORTATION VOCATIONAL COLLEGES UNDER THE BACKGROUND OF "THE BELT AND ROAD"

\section{A. Adjust Curriculum System According to the Need of "the Belt and Road" and the Cultivation of Students' Core Competence of Internationalization}

Core literacy emphasizes the key elements of students' social perspiration and life-long growth. The training of internationalized talents should break away from the traditional curriculum design method and change to the curriculum design with the goal of "patriotism + international outlook + high skills" for the students of traffic vocational colleges. In addition to traditional courses, we can increase the content of "all along 
the way" along the lines of history, culture, social economy, national religion, and other related courses.

"Trinity" curriculum system construction, patriotic education related courses in higher vocational colleges have relevant professional courses. Besides, ethnic cultural identity education should also be included in subject education and professional education. The education of the international outlook docks with the construction of the international professional curriculum system to adjust the professional curriculum system. In order to cultivate high-skill literacy, it is important to combine international certification system with international skills competition and international certification system to cultivate international skills literacy.

\section{B. Improving Teaching Methods Based on the Core Competence of International Talents with "the Belt and Road"}

How should teachers improve their teaching methods in the face of the challenges brought by "the Belt and Road" to higher vocational education in transportation?

First of all, we should improve self-efficacy in international teaching. Combining domestic and foreign teaching development level, teaching resources and students' situation, through the combination of in-class and out-of-class, we can further improve the sense of self-efficacy in teaching. We should adopt information-based teaching methods to improve students' participation both inside and outside the classroom. In teaching, we should "promote students' growth" and "make up for students' shortcomings" so as to deepen students' understanding of the sense of responsibility and mission of the motherland. Taking the multicultural integration of the "one belt along the road" as the material, the transportation enterprise culture and patriotic sentiment are integrated into the process of international education.

Secondly, it integrates foreign teaching methods and traditional teaching methods. We should constantly strengthen the links, communication and discussion with international advanced education and teaching teams, introduce advanced international curriculum training mode and innovative talents training, and through "Internet + education", teachers and students can grasp the cutting-edge technology knowledge and the latest technology development trends, so as to improve the "international outlook" of students. Finally, we should build a theoretical and practical teaching curriculum system that combines with the international community in order to cultivate students' international competitiveness. The aim of cultivating core literacy is to cultivate students 'lifelong learning ability, focusing on improving their competitiveness. Through exchange students, international competitions, international practice exchanges, joint training and other forms to broaden students' horizons, and achieve the "United States and the Communist" cooperation and development, enhance the international outlook.

\section{Establishing a Quality Evaluation System for Internationalization Core Literacy Training of Traffic Vocational Students}

Since 2000, foreign countries have begun to set up an evaluation system around the cultivation of core literacy. OECD has established PISA student core literacy evaluation project, which has attracted the attention of more than 70 countries. On this basis, based on the visibility of the assessment indicators, the EU has established the measurement of core literacy training.[5] On the road to internationalization of transportation education, how to establish a set of feasible evaluation criteria for training quality should be combined with three dimensions of students' patriotism, international outlook and high skills to establish a set of evaluation index system to upgrad and update the traditional evaluation index system of teaching quality and the evaluation index system of students' skill competitions to improve the level of education from the dimensions of international certification of professional education and international competition of professional education. In addition, an education evaluation system is established for the exchange between cross-border education and professional students to achieve comprehensive coverage of quality supervision.

\section{SOME Suggestions ON THE CULTIVATION OF INTERNATIONAL CORE LITERACY OF HIGHER VOCATIONAL TRANSPORTATION STUDENTS}

\section{A. Changing the Idea of Running a School}

Traffic vocational colleges should strengthen the global consciousness and ability in the training of craftsman spirit. UNESCO's concept of higher education has always been full of "global awareness", emphasizing that the actual situation of international, regional and national must be reflected in the teaching process in higher education. In the latest international strategy of education, the US Department of Education emphasizes that all students must master "global competence". In the process of reorganization of secondary institutions, Shaanxi Communications Vocational and Technical College has set up a special center for continuing education and international exchange. In the development plan of the 13th Five-Year Plan of the College, internationalization is clearly regarded as one of the main objectives of the future development of the College.

\section{B. Actively Exploring the "Going Out" Path of Higher Vocational Traffic Education}

Cooperation in running schools. With the development of industry, transportation higher vocational education should be closely associated with the National Overseas Transportation Construction projects. With the development of transportation construction projects, the cooperation of production capacity is deepening. It should be closely linked with the training of skilled personnel in relevant countries to train and understand the high-quality transportation construction talents who are interested in the national languages, laws and customs.

Develop student exchanges. All countries attach great importance to student exchanges. The "the Belt and Road" 
Vision and Action clearly states that China provides 10 thousand government scholarship places to each side of the country every year. Under the framework of the counterpart exchange school, students can be arranged to conduct shortterm learning experiences and internships to each other's school and expand their international vision. Traffic vocational education should be guided by Vision and Action and The Education Action of "the Belt and Road" issued by the Ministry of education in 2016.

To sum up, Higher Vocational Colleges of communications should "practice hard their internal skills" and make progress. According to their respective school running characteristics of the 30 higher vocational colleges, they should continue to innovate with the "go global" enterprises in order to adapt to the requirements of internationalized school running under the "one belt and one way" strategy, so as to achieve the goal of "going global" in vocational education at an early date.

\section{Deepening School-Enterprise Cooperation and Introducing Overseas Construction Standards and Other Post Literacy into Teaching System}

At present, the biggest problem is that internationalization and teaching are two different layers and the post-literacy such as overseas construction standards are not included in the teaching system. It is still the traditional teaching mode. Teaching is mainly based on "textbooks", which disjoints teaching from actual job requirements. Looking at the training of German higher vocational colleges, with the objective of serving the actual needs of the post, there are no fixed textbooks, teaching contents are updated in time, teaching forms are flexible and diverse, and the seamless docking between what we have learned and what we have done is realized.

\section{Open Traffic International Vocational Qualification Certificate and International Vocational Skills Competition Training}

At present, most of the domestic maritime vocational colleges have introduced the vocational qualification certificate training approved by the International Maritime Organization to train teachers and students with corresponding qualification certificates. At present, the professional qualification training of international logisticians and international accountants is seldom introduced into domestic transportation colleges. Through international general traffic vocational qualification training and international vocational skills competition training, we can effectively improve the employability.

\section{CONCLUSION}

The "the Belt and Road" initiative has brought new opportunities and challenges to the internationalization of transportation vocational colleges. We should timely summarize the problems existing in the internationalization of schools and improve the professionalism of transportation vocational students. By changing the concept of running a school, actively exploring new ways of Chinese-foreign cooperation in running a school, actively opening up the plight of international general vocational qualification certificate training for transportation, the overseas construction standards and techniques will be incorporated into the vocational literacy training system, so as to achieve the normalization of International Literacy training, and cultivate the internationalization core literacy of vocational transportation students in an all-round way.

\section{REFERENCES}

[1] “The Belt and Road” Big Data Report [M]. The Commercial Press, 2018.

[2] Zhou Guping, Yan Yue. Talent Support and Education Path of the "One Belt, One Road” Strategy [J]. Educational Research, 2015(10).

[3] Ministry of Education. Opinions on Deepening Curriculum Reform and Implementing the Fundamental Tasks of High Moral Values Establishment and People Cultivation [EB / OL]. (2014-4-16). Http://www.moe.edu.cn /publicfiles/business/htmlfiles/moe/s7054 /201404/167226. html.

[4] Shen Qi. Lack of Talents to Apply for Heat - small language between hot and cold [N]. Guangming Daily. 2014-12-18.

[5] Zhang Na. UNESCO's Core Literacy Research and Its Enlightenment [J] Education Guide, 2015 (7). 